American University Washington College of Law

Digital Commons @ American University Washington College of

Law

Articles in Law Reviews \& Other Academic Journals

Scholarship \& Research

2016

Evaluating Appropriability Defenses for the Exclusionary Conduct of Dominant Firms in Innovative Industries

Jonathan Baker

Follow this and additional works at: https://digitalcommons.wcl.american.edu/facsch_lawrev

Part of the Antitrust and Trade Regulation Commons 


\title{
EVALUATING APPROPRIABILITY DEFENSES FOR THE EXCLUSIONARY CONDUCT OF DOMINANT FIRMS IN INNOVATIVE INDUSTRIES
}

\author{
JONATHAN B. BAKER*
}

In the 2004 Trinko decision, the Supreme Court observed that "[t]he opportunity to charge monopoly prices-at least for a short period-is what attracts 'business acumen' in the first place; it induces risk taking that produces innovation and economic growth." The Court offered this remark to explain why anticompetitive conduct is included as an element of the monopolization offense and to provide a basis for questioning whether a unilateral refusal to deal would satisfy that element. ${ }^{2}$

The Court's observation invites dominant firms in innovative industries to defend against a monopolization challenge to their exclusionary conduct in three ways, ${ }^{3}$ collectively called here an "appropriability defense." ${ }^{4}$ The de-

\footnotetext{
* Professor of Law, Washington College of Law, American University. The author is indebted to Rick Brunell, Joseph Drexl, Katie Glynn, Keith Hylton, Louis Kaplow, Rosie Lipscomb, Paolo Ramezzana, Steve Salop, Carl Shapiro, John Woodbury, and to participants in the Searle Center's Seventh Annual Conference on Antitrust Economics and Competition Policy, the Haifa-Loyola workshop on Recent Challenges to Antitrust, and the Twenty-Fifth Annual Meeting of the American Law and Economics Association.

${ }^{1}$ Verizon Commc'ns Inc. v. Law Office of Curtis V. Trinko, LLP, 540 U.S. 398, 407 (2004) (dictum).

${ }^{2}$ The Court explained:

To safeguard the incentive to innovate, the possession of monopoly power will not be found unlawful unless it is accompanied by an element of anticompetitive conduct.... Firms may acquire monopoly power by establishing an infrastructure that renders them uniquely suited to serve their customers. Compelling such firms to share the source of their advantage is in some tension with the underlying purpose of antitrust law, since it may lessen the incentive for the monopolist, the rival, or both to invest in those economically beneficial facilities. Id. at $407-08$.

${ }^{3}$ Throughout this article, the term "exclusion" encompasses conduct that disadvantages rivals-for example by raising their costs or reducing their access to customers without necessarily inducing them to exit-as well as the complete foreclosure of rivals.

${ }^{4}$ Although this article is concerned only with antitrust challenges to the exclusionary conduct of dominant firms, an appropriability defense could also be employed in other contexts, including as an argument against liability for price fixing. Its possible application as a defense against
} 
fense could be an argument against liability: that the challenged conduct benefits competition by increasing the return to the dominant firm's investment in research and development $(R \& D)$, thereby enhancing that firm's incentives to invest and the prospects for industry innovation. Relatedly, it could take the form of an argument for construing the antitrust laws narrowly to avoid proscribing the conduct in question, in order to avoid chilling dominant firm $R \& D$ investment and industry innovation. In addition, it could take the form of an argument against a particular remedy, such as a requirement that the dominant firm sell to an excluded rival or otherwise collaborate with that rival. The dominant firm may argue that the remedy would reduce the return to its investment in $R \& D$, again lessening the dominant firm's incentives to invest and the prospects for industry innovation.

The term "appropriability" highlights the analogy between these arguments and a familiar economic argument for patents: that the ability of patent holders to exclude others allows them to earn a greater profit by appropriating a larger share of social gains from their innovations, and that prospect provides prospective innovators with incentives for $R \& D$ investment.

Because an appropriability defense emphasizes incentives to undertake R\&D investment, it may be particularly attractive to dominant firms in hightech markets. Microsoft argued on appropriability grounds that the antitrust laws should be construed narrowly in response to the government's monopolization complaint. The firm's economic expert contended, among other things, that any relief that would reduce the profits to successful software development would harm competition and consumers by lessening Microsoft's and other firms' incentives to develop new and better software. ${ }^{5}$ Similarly, Intel,

anti-merger enforcement is discussed in C. Scott Hemphill, Higher Profits as a Merger Defense: Innovation, Appropriability, and the Horizontal Merger Guidelines, in EUROPEAN COMPETITION LAw ANNuAL: 2010, at 43 (Philip Lowe \& Mel Marquis eds., 2013). Appropriability arguments have also been deployed in opposition to a no-fault monopoly offense, the essential facilities doctrine, and compulsory access to joint ventures, and in favor of research and development joint ventures. See, e.g., Richard M. Brunell, Appropriability in Antitrust: How Much Is Enough?, 69 ANTITRust L.J. 1, 6-27 (2001).

${ }^{5}$ Microsoft's expert contended that the government's antitrust theory would "outlaw" common practices and basic techniques of marketing and product development in the microcomputer software industry by subjecting firms to antitrust liability "solely" because of their success. Richard L. Schmalensee, Direct Testimony I[ 622, United States v. Microsoft Corp., Nos. 98-1232, 98-1233, 1999 WL 34757070 (D.D.C. Jan. 13, 1999). He further maintained that the remedies sought by the government, as well as the economic analysis of government witnesses that suggested that such remedies were necessary, "could lead to a serious reduction in investment in the personal computer software industry, with devastating long-run consequences to consumers and the U.S. economy." Id. If 623. This prediction was based on concerns about appropriability. Id. II 616 ("If investors believe that they will be denied these returns [to successful investments] due to regulatory actions, it is likely that their willingness to fund the development of the next generation of innovative technologies will be greatly reduced."). This case is discussed further in Part II.A below. 
another large high-tech firm, expressed concern that the relief contemplated by the Federal Trade Commission against alleged exclusionary conduct would discourage product improvements by restricting the way that Intel designed new products and exercised its intellectual property rights. ${ }^{6}$

The courts have given the appropriability defense a mixed reception. The Supreme Court explicitly rejected it when it was proffered by the dominant firm in Kodak. To similar effect, an influential district court decision in United Shoe Machinery rejected the defense both on the law and the facts. ${ }^{8}$

\footnotetext{
${ }^{6}$ Answer of Respondent Intel Corp. at 5, Intel Corp., FTC Docket No. 9341 (Dec. 31, 2009), www.ftc.gov/sites/default/files/documents/cases/091231respanswertocmplt.pdf ("The relief contemplated by the Complaint would require Intel to delay or even forgo product improvements unless it could simultaneously ensure that such improvements equally benefited Intel competitors, essentially requiring Intel to design its products for the benefit of its competitors rather than for its own benefit and the benefit of consumers."); see also id. at 8 (The complaint "seek[s] to strip Intel of intellectual property rights earned by Intel over many years of dedicated research and enormous investment."). The FTC's wide-ranging exclusionary conduct complaint was settled by consent in 2010. See Intel Corp., FTC Docket No. 9341 (Oct. 29, 2010) (Decision \& Order), www.ftc.gov/sites/default/files/documents/cases/101102inteldo.pdf.

${ }^{7}$ Eastman Kodak Co. v. Image Technical Servs., Inc., 504 U.S. 451 (1992) (upholding circuit court reversal of the district court's award of summary judgment to defendant Kodak on plaintiff's monopolization, attempted monopolization, and tying claims). Kodak had appealed to appropriability as a defense to plaintiff's Sherman Act Section 2 claims when setting forth a freerider rationale for refusing to sell copier parts to the independent service organizations (ISOs). The Court rejected its argument, as a matter of law, as inconsistent with precedent.

Kodak claims that its policies prevent ISO's from "exploit[ing] the investment Kodak has made in product development, manufacturing and equipment sales in order to take away Kodak's service revenues." Kodak does not dispute that respondents invest substantially in the service market, with training of repair workers and investment in parts inventory. Instead, according to Kodak, the ISO's are free-riding because they have failed to enter the equipment and parts markets. This understanding of free-riding has no support in our case law. To the contrary, as the Court of Appeals noted, one of the evils proscribed by the antitrust laws is the creation of entry barriers to potential competitors by requiring them to enter two markets simultaneously.
}

Id. at 485 (citation and footnote omitted). In this passage, the Court explains that the dominant firm's exclusionary conduct (involving equipment and parts) will reduce rivals' incentives to invest (in service), leading to less future competition (in service). This argument can be understood as rejecting Kodak's appropriability defense on the ground that the dominant firm failed to explain why its alleged disincentive to invest (in equipment and parts, but perhaps also in service in the long run) would lead to less investment overall, accounting for investment by both the dominant firm and its rivals, and, in consequence, harm future competition.

${ }^{8}$ United States v. United Shoe Mach. Corp., 110 F. Supp. 295, 345 (D. Mass. 1953), aff'd, 347 U.S. 521 (1954) (finding unlawful monopolization by the leading manufacturer of shoemaking machinery). The court explained:

Defendant seems to suggest that even if its control of the market is not attributable exclusively to its superior performance, its research, and its economies of scale, nonetheless, United's market control should not be held unlawful, because only through the existence of some monopoly power can the thin shoe machinery market support fundamental research of the first order, and achieve maximum economies of production and distribution. To this defense the shortest answer is that the law does not allow an enterprise that maintains control of a market through practices not economically inevitable, to justify that control because of its supposed social advantage. . . Moreover, if the defense were available, United has not proved that monopoly is economically com- 
By contrast, the Supreme Court in Trinko cited appropriability as the reason that anticompetitive conduct is included as an element of the monopolization offense and as a basis for questioning whether a unilateral refusal to deal would satisfy that element. ${ }^{9}$ Moreover, in a notable monopolization decision addressing alleged predatory innovation, the Second Circuit in Berkey Photo expressed resistance to finding antitrust liability when doing so would force dominant firms to pre-disclose product improvements to rivals or otherwise share the financial rewards to innovation, in part based on the appropriability concern that such relief would undermine dominant firm incentives to invest in $R \& D$ and develop new products..$^{10}$

The appropriability defense highlights one economic mechanism by which exclusionary conduct may affect a dominant firm's incentives to innovate: it could increase what the dominant firm anticipates earning from innovation, thereby enhancing that firm's incentive to invest in R\&D. But the same conduct may also discourage R\&D investment by the dominant firm's rivals, by reducing what those firms anticipate earning from innovation. Under circumstances discussed below, moreover, when rivals invest less, the dominant firm will have less incentive to invest - thereby reducing or even reversing the boost to the dominant firm's investment incentives resulting from increased appropriability. For these reasons, innovation incentives overall, accounting for both the dominant firm and its rivals, need not increase.

Antitrust enforcement against exclusionary conduct by a dominant firm may thus increase overall innovation incentives, even though its immediate consequence is to reduce what the dominant firm anticipates earning from innovation. When enforcement encourages the formerly excluded rivals to invest in $R \& D$, the dominant firm may have an incentive to increase its own

pelled by the thinness of the shoe machinery market. It has not shown that no company could undertake to develop, manufacture, and distribute certain types of machines, unless it alone met the total demand for those types of machines. Nor has United affirmatively proved that it has achieved spectacular results at amazing rates of speed, nor has it proved that comparable research results and comparable economies of production, distribution and service could not be achieved as well by, say, three important Id. shoe machinery firms, as by one.

9 Verizon Commc'ns Inc. v. Law Office of Curtis V. Trinko, LLP, 540 U.S. 398, 407-08 (2004).

${ }^{10}$ Berkey Photo, Inc. v. Eastman Kodak Co., 603 F.2d 263, 284-85 (2d Cir. 1979) (deeming it impossible to find Kodak liable for failing to take corrective action on its own for unadjudicated prior offenses, concluding that a continuing predisclosure requirement would confer benefits on rivals disproportionate to the competitive harms, and cautioning against a decree that might stifle future innovation); see also SCM Corp. v. Xerox Corp., 463 F. Supp. 983, 1001 (D. Conn. 1978) (seeking to avoid construing the antitrust laws to require sharing with competitors the financial rewards to innovation, as doing so could harm investment incentives and "risk inhibiting the commercialization of patented inventions to an extent inconsistent with the purposes of the patent laws"), remanded, 599 F.2d 32 (2d Cir. 1979). 
$R \& D$ investment in response, thereby reducing or reversing the disincentive to $R \& D$ investment that flows from a reduction in the dominant firm's anticipated profits from innovation. In consequence, antitrust enforcement attacking dominant firm exclusion may enhance innovation incentives overall, ${ }^{11}$ contrary to what the Supreme Court in Trinko suggested.

This article sets forth an analytical framework for evaluating whether condemning exclusionary behavior by a dominant firm under the antitrust laws would benefit overall prospects for market innovation notwithstanding the dominant firm's contention that the practices encourage its R\&D effort by enhancing appropriabilty. More specifically, the framework evaluates whether a dominant firm would be expected to increase its own $\mathrm{R} \& \mathrm{D}$ efforts in response to increased R\&D by its rivals. If so, antitrust enforcement against dominant firm exclusion would have two opposing effects on a dominant firm's incentive to invest in R\&D. That firm's innovation incentives would be discouraged by a reduction in the anticipated returns to R\&D investment, as emphasized by the appropriability defense. But if a prohibition on exclusionary conduct leads rivals to invest more in $R \& D$, the dominant firm's innovation incentives would simultaneously be enhanced, lessening or even reversing the implications of reduced appropriability for dominant firm R\&D. The latter dynamic would tend to undermine the dominant firm's appropriability defense and make it more likely that when the consequences of antitrust enforcement for rival investment are also taken into account, industry innovation incentives would be enhanced overall. Accordingly, when a dominant firm would be expected to increase its own $R \& D$ effort in response to increased R\&D by its rivals, the dominant firm's anticipated response calls into question whether to credit its appropriability defense.

Part I discusses the relevant economic theory and sets forth the framework for evaluating whether the dominant firm would be expected to increase its own R\&D effort in response to increased R\&D by its rivals. In Part II, the facts of well-known monopolization cases against dominant firms in different markets-Microsoft, IBM, and Xerox-are used to illustrate how the framework can be applied to determine whether to question or accept a dominant firm's appropriability defense in the context of antitrust enforcement.

\section{EVALUATING AN APPROPRIABILITY DEFENSE}

The economics literature provides two main reasons to expect that exclusionary conduct that enhances a dominant firm's profits from innovating would not lead to increased innovation incentives overall, accounting for both

\footnotetext{
${ }^{11}$ See generally Jonathan B. Baker, Exclusionary Conduct of Dominant Firms, R\&D Competition, and Innovation, 48 REv. INDUs. ORG. 269 (2016) [hereinafter Baker, Exclusionary Conduct].
} 
the dominant firm and for its rivals. ${ }^{12}$ First, the empirical economics literature suggests that on average, the incentive to innovate to escape product market competition plays at least as large a role in fostering innovation as the incentive to obtain a greater reward for innovation success. ${ }^{13}$ This observation suggests caution in crediting the appropriability defense generally ${ }^{14}$-a posture which is also warranted because the social costs of erroneously insulating exclusionary conduct involving innovation from antitrust enforcement may be substantial ${ }^{15}$ - but it does not provide a framework for evaluating the defense in individual cases.

12 These are not the only reasons that exclusionary conduct may reduce overall prospects for innovation. See generally Brunell, supra note 4, at 29-37 (discussing six counterarguments to the incentive argument for a permissive antitrust regime). Cf. Marina Lao, Ideology Matters in the Antitrust Debate, 79 ANTITRust L.J. 649, 661-62 (2014) (setting forth reasons why the imposition of a unilateral duty on a monopolist to deal with its rivals could either enhance or reduce industry innovation).

${ }^{13}$ See generally Jonathan B. Baker, Beyond Schumpeter vs. Arrow: How Antitrust Fosters Innovation, 74 ANTITRUST L.J. 575, 583-86 (2007) [hereinafter Baker, Beyond Schumpeter vs. Arrow]; see also Carl Shapiro, Competition and Innovation: Did Arrow Hit the Bull's Eye?, in The Rate and Direction of Inventive Activity Revisited 361, 376-82 (Josh Lerner \& Scott Stern eds., 2012); John T. Scott \& Troy J. Scott, Innovation Rivalry: Theory and Empirics, 41 Economia e Politica Industriale 25 (2014). Cf. Chad Syverson, What Determines Productivity?, 49 J. ECON. LITERATURE 326, 351-57 (2011) (greater market competition enhances productivity by encouraging the adoption of costly actions to raise productivity and by inducing the exit of less productive firms); $i d$. at 336-39 (product market competition is associated with the adoption of best practices in management).

The Schumpeterian growth literature does not bear directly on the consequences for overall industry innovation of the types of dominant firm exclusionary conduct considered in this article. That literature concludes that greater product market competition fosters $R \& D$ investment by all firms in sectors where the firms operate at the same technological level, Philippe Aghion et al., The Causal Effects of Competition on Innovation: Experimental Evidence 2, 10 (Nat'1 Bureau of Econ. Research, Working Paper No. 19987, 2014), and suggests that in the event that product markets were to grow more competitive, the innovation incentives of a dominant firm with a technological lead would remain high. Philippe Aghion, Ufuk Akcigit \& Peter Howitt, What Do We Learn from Schumpeterian Growth Theory? 13-14 (Nat'l Bureau of Econ. Research, Working Paper No. 18824, 2013) (Prediction 2 \& Figure 2) (explaining that greater product market competition in markets with a technological leader mainly operates to discourage R\&D investment by laggards until they have caught up). Carl Shapiro emphasizes that this literature models increased product market competition as arising from greater imitation (hence reduced appropriability for entrants) rather than as arising from increased contestability (hence increased appropriability for entrants). Shapiro, supra, at 372-74. The antitrust interventions considered in this article would increase entrant appropriability, consistent with the latter perspective.

${ }^{14}$ See generally Jonathan B. Baker, "Dynamic Competition" Does Not Excuse Monopolization, Competition Pol'y INT'L, Autumn 2008, at 243 (concluding that a concern for appropriability of $R \& D$ investments does not justify relaxing antitrust prohibitions against monopolization).

${ }^{15}$ If entrenched business interests-dominant firms and industry participants acting collectively as though they were a dominant firm-are allowed to employ exclusionary conduct to prevent the introduction of new products, new technologies, and improved ways of doing business, the harm may go beyond the fortunes of individual industries and their customers to threaten economy-wide growth and prosperity. See generally Jonathan B. Baker, Exclusion as a Core Competition Concern, 78 ANTiTRust L.J. 527, 559-60 (2013). A full analysis of innovation-related error costs would also consider the possibility that the prospect of antitrust enforce- 
The second reason is the observation that in many markets the dominant firm's payoff from innovation, and thus its incentives to invest in $R \& D$, would likely remain high even if its exclusionary conduct is prohibited because of market features ensuring that the dominant firm would continue to profit substantially from successful innovation. These may include rapid market growth, scale economies, network effects, sale of complementary products, and high customer switching costs. ${ }^{16}$ This observation provides a basis for rejecting the dominant firm's appropriability defense when the relevant markets have these features, but leaves open the treatment of the defense in markets that do not.

This article provides a framework for evaluating whether the dominant firm's incentives to invest in R\&D would remain high following the prohibition of exclusionary conduct and thus for questioning the dominant firm's appropriability defense in markets where the defense cannot be rejected on the ground that market features would likely preserve a strong incentive for the dominant firm to invest in R\&D after its exclusionary conduct is prohibited. The framework is based on assessing the impact of increased R\&D investment by rivals on the investment incentives of the dominant firm. ${ }^{17}$

This article presumes that, by excluding rivals from a product market, the dominant firm would reduce those rivals' incentive to invest in $R \& D$ aimed at developing a competing product ${ }^{18}$ and thus that prohibiting the exclusionary practices would increase rivals' $R \& D .{ }^{19}$ When the dominant firm engages in exclusionary conduct, its rivals are less likely to escape competition through

ment would chill procompetitive R\&D. For a discussion of error cost analysis, see generally Jonathan B. Baker, Taking the Error out of "Error Cost" Analysis: What's Wrong with Antitrust's Right, 80 ANTITRUST L.J. 1 (2015).

${ }^{16}$ Brunell, supra note 4, at 32 (attributing this observation to Timothy Bresnahan in the policy discussion of the Microsoft litigation); see also Baker, Beyond Schumpeter vs. Arrow, supra note 13, at 593-98. Cf. Richard C. Levin, Appropriability, R\&D Spending, and Technological Performance, 78 Am. ECON. Rev. (PAPERS \& Proc.) 424 (1988) (imperfect appropriability allowing intra-industry $R \& D$ spillovers encouraged rapid technological progress in electronics-based industries without discouraging $R \& D$ investment).

${ }^{17}$ These two possibilities- that market features may give the dominant firm a substantial payoff from $R \& D$ investment even if competition is increased, and that the dominant firm may have an incentive to increase its $R \& D$ investments in response to increased $R \& D$ investment by its rivals-may collectively offer an explanation for the empirical observation that on average, competition increases investment incentives overall.

${ }^{18}$ The relevant R\&D investments are those aimed at developing products that would substitute for a next-generation product that the dominant firm is pursuing. Rivals may have an increased incentive to develop products that would complement a next-generation product, but the antitrust concern is typically with investment within the product market. R\&D investment in developing complementary products is not addressed in this article.

${ }^{19}$ If an excluded rival pursues ways of inventing around a roadblock created by the dominant firm, its nominal $R \& D$ expenditures could remain high and even grow. It is nevertheless appropriate to describe the rival as investing less in R\&D relative to a but-for world in which there was no exclusionary conduct, for two reasons: absent the exclusionary conduct, the rival may have 
innovation, so would have less incentive to invest in R\&D. Another justification for the presumption is an appropriability argument: with less ability to obtain customers, excluded rivals would expect a lower payoff from their R\&D investments and so would have less incentive to invest. In addition, the factors that tend to call into question the dominant firm's appropriability argument, discussed below, simultaneously tend to reinforce the connection between dominant firm exclusion and reduced rival $R \& D$ investment. ${ }^{20}$ Hence, in a litigation context, the assumption that rivals would invest more absent dominant firm exclusionary conduct is most likely to be correct when it matters most: i.e., when, as the framework set forth in this article suggests, the dominant firm's appropriability defense should not be credited.

\section{A. Product Market Exclusion and R\&D Investment Rivalry}

To keep the economic analysis simple, this discussion makes a number of assumptions. First, the dominant firm and its rivals compete in selling the current generation of a product and in developing next-generation products. ${ }^{21}$ Second, the foreclosure concern is with dominant firm conduct that excludes its rivals from a product market, not with dominant firm conduct that raises the costs of rival R\&D. ${ }^{22}$ Third, rivals are excluded from the post-innovation product market; pre-innovation product market competition is unaffected by the exclusionary conduct. ${ }^{23}$ It is reasonable to focus solely on post-innovation

been able to avoid some of those expenditures or to pursue more promising approaches to upgrading its product.

${ }^{20}$ When a dominant firm's appropriability defense can be questioned on the ground that the dominant firm would have an incentive to invest more in $R \& D$ in response to greater rival $R \& D$ investment, rivals would be expected to respond to reduced dominant firm R\&D investment by increasing their own R\&D investment. See Baker, Exclusionary Conduct, supra note 11, at 8 (discussing how two factors which suggest that the dominant firm would respond to greater rival R\&D investment by investing more also suggest that rivals would respond to reduced dominant firm investment by investing more). A third factor that is also discussed below, the dominant firm's sale of complements, would not influence rivals' response to changing levels of dominant firm investment. Hence, rivals' $R \& D$ investment would increase beyond the boost derived from their greater ability to appropriate the profits from successful innovation, which would result from antitrust condemnation of the dominant firm's exclusionary conduct. Accordingly, when a dominant firm's appropriability defense is questioned based on the framework set forth in this article, it is reasonable to assume that prohibiting exclusionary conduct would increase rival investment in R\&D.

${ }^{21}$ In the case examples discussed in Part II, the firms compete to develop new products, consistent with this assumption. Cf. F.M. SCHERER, The Theory of Market Structure and Innovation, in Innovation and Growth: Schumpeterian Perspectives 59, 60 (1986) (viewing "most industrial R\&D [as] product oriented" rather than cost-saving process R\&D). The related economic theory article is also concerned mainly with new product development. Baker, Exclusionary Conduct, supra note 11.

22 The conditions that would suggest questioning a dominant firm's appropriability defense for product market exclusion would also suggest questioning such a defense if offered to justify conduct raising rivals' R\&D costs. See Baker, Exclusionary Conduct, supra note 11, at 16-17.

${ }^{23}$ The effect of exclusionary conduct on dominant firm innovation incentives may depend on whether the dominant firm excludes its rival from pre-innovation competition or post-innovation 
exclusion when evaluating the appropriability defense because the dominant firm will not proffer that defense unless it is concerned with the incentive consequences of post-innovation product market competition. ${ }^{24}$ Fourth, the dominant firm's exclusionary conduct discourages R\&D and innovation by its rivals, ${ }^{25}$ while increasing the expected return to dominant firm innovation. Fifth, the primary competitive concern is with innovation, not price. ${ }^{26}$ Finally,

competition because the direct effects would be expected to go in opposite directions: pre-innovation exclusion would reduce the dominant firm's incentive to innovate in order to escape competition, while post-innovation exclusion would enhance the dominant firm's appropriability incentive to innovate. See generally id.

${ }^{24}$ When exclusionary conduct would affect both pre-innovation and post-innovation competition, the dominant firm's innovation incentive would likely depend primarily on the consequences for post-innovation competition, the concern in this article, as the present value of dominant firm profits in product markets after new products are introduced would commonly be expected to exceed its profits while R\&D is underway but before the products are introduced. This generalization is not inconsistent with the successive innovation model of Segal and Whinston. Ilya Segal \& Michael D. Whinston, Antitrust in Innovative Industries, 97 Am. ECon. Rev. 1703, 1718-23 (2007). In that model, successful entrants displace incumbents but then become subject to the possibility of displacement by future entrants. Segal and Whinston find that antitrust enforcement prohibiting exclusionary conduct increases the present value of entrant profits from $R \& D$, leads the entrant to increase its $R \& D$ investment, and raises the probability of entrant innovation success when it increases the profits an entrant earns before it is displaced by more than it reduces the discounted future profits an entrant earns after it is displaced. The profits an entrant earns before it is displaced may be understood as the innovator's post-innovation profits, and the profits it earns after it is displaced include the possibility of profiting through future reentry and thus may be viewed as future pre-innovation profits. Cf. Joshua S. Gans, When Is Static Analysis a Sufficient Proxy for Dynamic Considerations? Reconsidering Antitrust and Innovation, in 11 InNovation Policy AND THE ECONOMY 55, 63 (Josh Lerner \& Scott Stern eds., 2011) (Segal \& Whinston's model implies that the rate of entrant innovation increases by an antitrust prohibition on any incumbent firm's practice "whose profitability is dependent on a reduction in entrant innovation.").

${ }^{25}$ The exclusionary conduct is assumed to reduce rival $R \& D$ investment even after accounting for indirect effects involving the rival's response to changes in the dominant firm's R\&D investment. See supra notes $18-20$ and accompanying text. This assumption allows the analysis to focus on other economic questions: whether the exclusionary conduct raises or lowers the R\&D investment of the dominant firm, and, assuming that it raises that investment, whether total investment will increase or decrease, and whether economic welfare rises or falls.

${ }^{26}$ Although exclusionary conduct in product markets would likely also discourage price competition, this article focuses on its consequences for innovation. Cf. Yongmin Chen, Refusal to Deal, Intellectual Property Rights, and Antitrust, 30 J.L. ECON \& ORG. 533 (2014) (concluding that in a model with innovation and price competition upstream and price competition downstream, exclusionary conduct by a vertically integrated upstream producer limiting a potential rival's access to the downstream market may increase the upstream firm's likelihood of innovation by enhancing the return while reducing the likelihood of follow-on innovation and entry by the potential upstream rival, with ambiguous effects on innovation). Increased innovation is presumed to enhance social welfare regardless of whether courts and enforcers are concerned with consumer welfare or aggregate economic welfare. This presumption is consistent with the common conclusion of economists studying individual innovations that their benefits to society as a whole greatly exceed the benefits to the firms that develop them. In theory, however, excessive innovative effort may arise in cases where the innovator profits mainly by diverting business from its rivals rather than by expanding the market. The social welfare effects of an antitrust enforcement action would also depend on the consequences of the conduct for price competition, which are not analyzed here. 
the product market lacks features that would preserve the dominant firm's incentives to invest in R\&D even if its exclusionary conduct is prohibited, as such features would make it possible to reject the appropriability defense without additional analysis. ${ }^{27}$

Given these assumptions, dominant firm conduct excluding rivals from a post-innovation product market affects the dominant firm's incentives to invest in R\&D through two routes, one direct and one indirect. The direct route is emphasized by the appropriability story: putting aside influences arising from the way the firms interact, exclusionary conduct would increase the dominant firm's expected payoff to innovation and reduce the expected payoff to rivals, boosting dominant firm $R \& D$ investment and chilling rival $R \& D$ investment. The dominant firm's appropriability defense treats this dynamic as the primary influence on incentives to innovate, ${ }^{28}$ and tells the same story in reverse: it argues that antitrust enforcement limiting exclusionary conduct would allow rivals to innovate and compete, lessening the dominant firm incentive to invest in $R \& D$ even as it encourages rivals to invest.

This article emphasizes that the exclusionary conduct also affects dominant firm innovation incentives through a second and indirect route: by the way the dominant firm's incentives to invest in R\&D depend on the R\&D investments of its rivals. That influence could, in principle, go in either direction: greater rival investment could lead the dominant firm to invest either more or less than it would invest if only the direct route mattered. ${ }^{29}$ The dominant firm's response to the innovative effort of its competitors may be substantial even if the rivals are not characterized as disruptive entrants or mavericks and even if the rivals employ the same technology and business model as the dominant firm.

Considering only the direct effect, antitrust enforcement against exclusionary conduct would be expected to reduce dominant firm R\&D and increase rival $R \& D$, with ambiguous effects on overall innovation prospects. But if the dominant firm would respond to greater rival $R \& D$ by increasing its own $R \& D$ investments, then the indirect (strategic) and direct forces would influence dominant firm R\&D investment in opposing directions. If the indirect

\footnotetext{
${ }^{27}$ See supra note 16 and accompanying text.

${ }^{28}$ The appropriability defense also presumes that the boost to dominant firm incentives is more important than the chill to rival incentives in determining overall innovation incentives. This presumption is called into question by the empirical economics literature emphasizing the importance of the motive to escape product market competition for the incentive to innovate. Supra note 13 and accompanying text.

${ }^{29}$ The example in the appendix to this article identifies conditions under which the dominant firm would have an incentive to respond to greater rival investment by investing more (i.e., treating rival $\mathrm{R} \& \mathrm{D}$ as a strategic complement) or by investing less (i.e., treating rival $\mathrm{R} \& \mathrm{D}$ as a strategic substitute).
} 
force is more important, the direct effect will be completely reversed: the dominant firm will respond to antitrust enforcement by increasing its R\&D investment. Even if the direct route is the more important influence on dominant firm R\&D, an indirect force working in the opposite direction would dampen the direct effect, making it more likely that, after accounting for rival $\mathrm{R} \& \mathrm{D},{ }^{30}$ industry investment incentives will increase overall. ${ }^{31}$ Accordingly, a dominant firm's appropriability defense should be questioned, and often rejected, if the dominant firm would be expected to increase its own R\&D effort in response to increased $R \& D$ by its rivals. ${ }^{32}$

When the dominant firm would be expected to react this way, greater product market competition, the result of antitrust enforcement, would likely enhance overall innovation incentives by spurring $R \& D$ competition. Conversely, if the dominant firm would be expected to reduce its own R\&D effort in response to increased $R \& D$ by its rivals, that strategic response would be consistent with a dominant firm's appropriability defense..$^{33}$

\footnotetext{
${ }^{30}$ Analogous direct and indirect forces also influence rival investment incentives. Although this article's focus on the appropriability defense leads it to emphasize the forces affecting dominant firm incentives, a full economic analysis would consider both forces. See generally Baker, Exclusionary Conduct, supra note 11. If the direct and indirect effects on the dominant firm's innovation incentives are both small, the dominant firm's R\&D effort would not be affected substantially by antitrust enforcement against exclusionary conduct, so overall innovation incentives would depend primarily on the way an antitrust prohibition on exclusionary conduct affects rival innovation incentives. See supra note 16 and accompanying text (describing circumstances under which a dominant firm's innovation incentives would be largely unaffected by antitrust enforcement against its exclusionary conduct).
}

${ }^{31}$ Whether industry-wide innovation would benefit from rejecting an appropriability defense and prohibiting the exclusionary conduct depends on whether the social benefit of encouraging rival $R \& D$ investment exceeds the social harm of discouraging $R \& D$ investment by the dominant firm. The indirect effect of the dominant firm's response to rival R\&D investment could limit the harm side of that balance.

32 This discussion is concerned with the dominant firm's appropriability defense, not with the dominant firm's motive to exclude. The dominant firm may find exclusionary conduct profitable regardless of whether it would respond to an increase in rival $R \& D$ investment by increasing or reducing its own $R \& D$ efforts.

${ }^{33}$ A dominant firm might seek to support its appopriability defense by showing that that it would not have invested in $R \& D$ in the past had it not anticipated being able to exclude its rivals. The probative value of such a claim for showing that exclusionary conduct is needed to preserve the dominant firm's future incentive to invest in R\&D may depend on how that firm analyzed the benefits and costs of R\&D in the past (for example, whether it anticipated that it would lose a substantial market if both it and its rivals upgraded their products absent exclusionary conduct, and whether its past analysis accounted for the indirect as well as the direct effects of exclusionary conduct on its $R \& D$ incentives), and whether conditions are similar (for example, whether, absent the exclusionary practices, it would still be as susceptible to share erosion as it thought it was then, and whether new aspects of market structure would make R\&D investment attractive for the dominant firm absent the ability to exclude). Such evidence would bear on the dominant firm's incentives to invest in R\&D, as distinct from incentives overall. 


\section{B. The Dominant Firm's Response to Rival R\&D Investment}

The above analysis of the overall consequence of exclusionary conduct for innovation turns on whether the dominant firm would respond to increased rival $R \& D$ investment by increasing its own $R \& D$ investment - that is, on whether the dominant firm regards rival R\&D as what economists term a "strategic complement." If so, and if the strategic complementarity is sufficiently powerful, antitrust intervention to prevent exclusionary conduct by a dominant firm would be expected to encourage industry innovation on balance to the benefit of consumers. ${ }^{34}$ Under such circumstances, the dominant firm's appropriability defense should be rejected. ${ }^{35}$ If instead the dominant firm would respond to increased rival R\&D investment by reducing its own R\&D investment, that response would be consistent with the dominant firm's appropriability defense.

Firms often know a great deal about rival R\&D investments even though their level and nature is not fully transparent to outsiders before new products are introduced. Firms may know that rivals have an active R\&D effort, the technical expertise to purse next generation products, or a track record of successful product upgrades. Firms also commonly learn what their rivals tell investors about future products, and what $R \& D$ efforts industry observers think their rivals are pursuing. Firms may also learn about rivals' planned upgrades when those competitors discuss their needs and plans with input suppliers or retailers. Hence, it is reasonable to assume that when the R\&D investment incentives of industry participants change substantially-as would be expected when a dominant firm adopts challenged exclusionary practices or when a court prohibits those practices - that the dominant firm can make an informed judgment about the way the nature and level of its rivals' R\&D activity will change, that the dominant firm expects that its rivals can do the same with respect to the dominant firm's R\&D effort, and that the dominant firm can make an informed judgment about the way rivals' $R \& D$ investment will respond to changes in its own R\&D investments. Accordingly, it will commonly be appropriate to account for the way the dominant firm reacts to rival $R \& D$ in evaluating the innovation consequences of an antitrust challenge to its exclusionary conduct. ${ }^{36}$

\footnotetext{
${ }^{34}$ See generally Baker, Exclusionary Conduct, supra note 11.

${ }^{35}$ Even if the dominant firm's response is not sufficiently powerful for industry innovation incentives to increase overall, the presence of some response may mean that overall incentives do not decrease much, so there is little innovation cost to antitrust intervention. Then any net innovation benefit of increased appropriability may be more than offset by the harm to consumers from the loss in product competition arising from the exclusionary conduct, as when that conduct permits the dominant firm to maintain its market power.
}

${ }^{36}$ Even if the dominant firm's expectations about rival R\&D investment turn out to be incorrect in retrospect, moreover, those expectations are relevant to evaluating the innovation conse- 
Although the direction of a dominant firm's response to rivals' conduct can be difficult to anticipate, ${ }^{37}$ economic theory suggests an approach to doing so with respect to $R \& D$ investment. ${ }^{38}$ That approach is based on comparing the payoffs the dominant firm receives in various future situations defined by whether or not the dominant firm or its rivals successfully innovate. In particular, the dominant firm will treat rival R\&D investment directed toward new products as a strategic complement when the incremental benefit of innovation to the dominant firm is greater when rival innovation succeeds than when it fails. ${ }^{39}$ Intuitively, when a rival increases its $R \& D$ investment, the rival's likelihood of innovation success will increase. If the dominant firm's incremental gain from innovation success is greater when the rival succeeds than when the rival fails, the dominant firm will seek to improve its own prospects for innovation success by investing more in innovation, too, thus treating rival $\mathrm{R} \& \mathrm{D}$ as a strategic complement.

In consequence, the nature of the strategic interaction in $R \& D$ competition can be inferred from potentially observable aspects of market structure. Most importantly, as indicated in the example set forth as an appendix to this article, a dominant firm is more likely to treat rival R\&D as a strategic complement when (1) the dominant firm anticipates that it would have a high market share when both it and its rival successfully innovate, ${ }^{40}$ and (2) the dominant firm anticipates that it would lose a great deal of business to its rivals if the rivals innovate and it does not. ${ }^{41}$ Both factors increase the dominant firm's

quences of an antitrust prohibition on exclusionary conduct because they guide the dominant firm's $R \& D$ investment decisions.

${ }^{37}$ Cf. Brunell, supra note 4, at 4-6, 37-38 (emphasizing difficulty of determining whether to prefer appropriability arguments or competition counterarguments in general or on a case-bycase basis); Lao, supra note 12, at 661 ("It is difficult to predict reliably the incentive and net innovation effects of antitrust enforcement against dominant firm conduct.").

${ }^{38}$ The dicusssion in the text is based on the related economics article: Baker, Exclusionary Conduct, supra note 11. Outside of that framework, suppose that firms can finance R\&D less expensively out of retained earnings than through external finance, perhaps because of information asymmetries between innovators and investors or lenders. Then, one might imagine that exclusionary conduct by an innovator would simultaneously reduce rival R\&D investment and raise the innovator's $R \& D$ investment through direct effects on the cost and availability of capital not related to the strategic issues emphasized here. In this dynamic, the innovator would behave as though its rival's R\&D investment is a strategic substitute, although the reason that R\&D investments are negatively correlated would not be strategic. Such a capital markets imperfection is more likely to matter to an entrant or fringe rival than to the large and established dominant firms in the case examples considered below, however, so will not be considered further in this article.

${ }^{39}$ See Baker, Exclusionary Conduct, supra note 11, at 7.

${ }^{40}$ Conversely, if the dominant firm expects that its high share could substantially erode if both it and its rivals innovate, perhaps because its success with current-generation customers gives it little advantage in attracting next-generation customers, then it may have an incentive to treat rival $R \& D$ as a strategic substitute, consistent with its appropriability defense.

${ }^{41}$ Conversely, if the dominant firm anticipates that it would not lose much business to its rivals in the event the rivals alone introduced new products, the dominant firm would have an 
incremental gains from developing a next-generation product when its rivals introduce an upgrade- the first factor by raising the benefits of dominant firm innovation when rivals also innovate, and the second by raising the cost to the dominant firm of not matching rival innovation. Hence each increases the dominant firm's incremental benefit from new product introduction given that its rivals also do so, relative to the firm's incremental benefit when its rivals do not upgrade.

The example in the appendix also points to a third factor relevant to determining whether the dominant firm will regard rival R\&D as a strategic complement: the nature and extent of competition in markets for complementary products. When a new product introduction is expected to increase the sales of complementary products, ${ }^{42}$ and those sales would be very profitable to the dominant firm (as when it is the only seller of the complementary goods), the dominant firm would care mainly about ensuring that some firm introduce a new product, so its incremental gain from upgrading its own product conditional on its rival introducing a new product would be small. In consequence, the dominant firm would not treat rival R\&D as a strategic complement. ${ }^{43}$

The case studies in the next Part illustrate how to analyze these three factors-the dominant firm's likely market share when both firms innovate, the dominant firm's likely customer loss if a rival upgrades when it does not, and the impact of innovation on the dominant firm's profits in the sale of comple-

incentive to regard rival $R \& D$ as a strategic substitute. This observation is consistent with the conduct of the Big Three U.S. automakers (Chrysler, Ford, and General Motors) during the 1970s. The large U.S. firms accommodated the aggressive research and development of thensmall Japanese rivals (Nissan and Toyota) in developing subcompact models, most likely in part because the U.S. firms reasonably questioned the ability of their fringe rivals to expand, even with attractive new products. Jonathan B. Baker, Fringe Firms and Incentives to Innovate, 63 ANTITRUST L.J. 621, 637 (1995). Three other factors also may have encouraged the Big Three to regard fringe firm $R \& D$ as a strategic substitute: their desire to avoid cannibalizing the sales and profits of their existing midsize automobiles, risk aversion, and the threat new products could pose to coordination among the Big Three firms. Id. at 634-39.

${ }^{42} \mathrm{~A}$ dominant firm in one market (hardware) may earn most of its profits on sales in that market while facing competition in a complementary product (content). See Ron Adner, Jianqing Chen \& Feng Zhu, Frenemies in Platform Markets: The Case of Apple's iPad vs. Amazon's Kindle 3-4 (Harv. Bus. Sch. Working Paper No. 15-087, 2015) (concluding that a smaller hardware platform may find it profitable to allow customers of a larger hardware platform to access its content, while the large hardware platform does not allow customers of the smaller platform similar access).

${ }^{43}$ This discussion assumes that the dominant firm's sale of complements is not a market factor that ensures that the dominant firm will continue to profit greatly from $R \& D$ investment even if it is prohibited from undertaking exclusionary conduct, although complements could play that role under some circumstances. See supra note 16 and accompanying text. If the dominant firm's payoff to $R \& D$ investment would remain high after antitrust enforcement for that reason, the dominant firm would continue to have a strong incentive to invest in $R \& D$ even if it did not regard rival $R \& D$ as a strategic complement, justifying a rejection of the dominant firm's appropriabilty defense without need to apply the analytical framework set forth in this article. See also infra note 73 and text accompanying note 100 . 
mentary products-to identify the likely response of dominant firms to increased $R \& D$ investment by a rival and evaluate whether to question an appropriability justification for the dominant firm's exclusionary conduct.

\section{ANALYZING AN APPROPRIABILITY DEFENSE IN THREE CLASSIC MONOPOLIZATION CASES}

This Part turns to three classic antitrust monopolization cases involving the development of new products: the government's monopolization case against Microsoft arising from that firm's exclusion of Netscape and Java, the IBM plug compatibility cases (which are treated as a single case), and the FTC's patent portfolio case against Xerox. Those cases are used to illustrate how the factors set forth in Part I can be employed to analyze the dominant firm's likely response to rival investment in R\&D. In discussing each case, this article will presume that antitrust enforcement would increase rival incentives to invest in R\&D and the likelihood that a rival will introduce a next generation product, and that the dominant firm argues against liability or relief on the ground that enforcement would lessen the dominant firm's incentive to invest in R\&D by reducing its reward to introducing a new product, harming innovation incentives overall. The discussion does not evaluate whether an appropriability defense should or should not have applied, but instead demonstrates the workability of the analytical framework by illustrating how the issue would be approached on the facts of each case. Although the cases discussed below cover a diverse set of competitive effects theories, they do not address the full range of exclusionary conduct that a dominant firm could seek to justify with an appropriability defense.

\section{A. Microsoft (Netscape and Java)}

In 2001, the D.C. Circuit upheld a district court decision finding that Microsoft, the dominant firm in personal computer operating systems, unlawfully maintained its monopoly power through exclusionary conduct. ${ }^{44}$ Microsoft's conduct indirectly excluded operating system rivals by impeding the success of two firms developing new products in complementary markets: Netscape, which was developing a browser, and Sun Microsystems, which was developing the Java programming language. These products had the potential to allow applications programs written for Microsoft's operating system to run on rival operating systems as well, thereby making rival operating

\footnotetext{
${ }_{44}$ United States v. Microsoft Corp., 253 F.3d 34 (D.C. Cir. 2001) (en banc). This high-profile litigation has been the subject of two books. ANDREw I. Gavil \& Harry FIrst, The MiCrosoft Antitrust Cases: Competition Policy for the Twenty-First Century (2014); William H. Page \& John E. Lopatka, The Microsoft Case: Antitrust, High-Technology, and ConSUMER WELFARE (2007).
} 
systems better substitutes for Microsoft's Windows and enhancing operating system competition with Windows.

Netscape was impeded through exclusivity agreements and other conduct that limited Netscape's access to key channels of product distribution. ${ }^{45}$ Sun was impeded through exclusivity agreements and other conduct that favored the distribution of Java with modifications created by Microsoft that would prevent software applications from working on personal computers that used Sun's Java. ${ }^{46}$ In the jargon of the case, Netscape and Sun's new products had the potential to erode the "applications barrier to entry" that limited the competitive prospects of Microsoft's operating systems rivals. ${ }^{47}$ By excluding these suppliers of third products, Microsoft forestalled the development of key building blocks that rival operating systems could use when developing next generation operating system products to make them compete better with Microsoft's Windows operating system. ${ }^{48}$ As a result, the prospects for future innovation and price competition in operating systems were reduced. ${ }^{49}$

Microsoft and its economic expert defended the firm's practices, in part on appropriability grounds, as protecting the incentives of software firms, including Microsoft, to develop new and better software products. ${ }^{50}$ As applied to Microsoft itself, this justification may be evaluated by analyzing how that firm would likely respond to increased innovative effort by its rivals or, more precisely in this case, how it would respond to increased innovative effort by firms selling complements when improvements to complementary products

${ }^{45}$ Microsoft, 253 F.3d at 59-74. The other exclusionary practices included integrating Microsoft's Internet Explorer browser into that firm's Windows operating system. According to a statement attributed to Microsoft, Microsoft intended to "cut off Netscape's air supply." John Schwartz, Government, Microsoft Present Contrary Views of Trial, WASH. Post, Aug. 11, 1999, at E3.

${ }^{46}$ Microsoft, 253 F.3d at $74-77$. The other exclusionary practices included deceiving Java developers about the Windows-specific nature of the tools Microsoft distributed to them and coercing Intel to stop aiding Sun in improving Java technologies. One Microsoft document described the firm's conduct as aimed at increasing the market for "polluted" Java. Id. at 77.

${ }^{47}$ See id. at 55 (defining "applications barrier to entry").

48 Together, Netscape's browser and Java had the potential to allow applications programs to access application programming interfaces, thereby allowing applications programs to run on any operating system supporting the browser and Java and, in consequence, eroding the applications barrier to entry that was protecting Windows from competition from rival operating systems. See id. at 53-56.

${ }^{49}$ The monopolization allegations-the primary focus of the litigation and the opinions of the district and appeals courts - focused on competitive harms in an operating system market. The public debate over Microsoft's conduct also concerned possible competitive harms in a browser market.

${ }^{50}$ See supra note 5; see also Brunell, supra note 4, at 28 (discussing testimony of Microsoft's economic expert, Richard Schmalensee). In addition, Microsoft's "freedom to innovate" advocacy outside the courtroom could be understood as resting implicitly on an appropriability justification. E.g., Ads in Newspapers Take Microsoft's Case to Its Users, Seattle Times (Apr. 9, 1998), community.seattletimes.nwsource.com/archive/?date=19980409\&slug=2744284. 
would increase the ability of rival operating systems to compete with Windows. ${ }^{51}$ If Microsoft would be led to increase its own innovative efforts, its response would provide a reason to question Microsoft's appropriability justification for its exclusionary conduct. ${ }^{52}$

Testimony by Microsoft's economic expert, interpreted through the lens of the analytical framework set forth in Part I above, raises the possibility that Microsoft would have behaved this way. According to that testimony, with software generally and, presumably, operating systems in particular, rivals need to leapfrog incumbents in order to succeed. Because customers make investments predicated on their existing software, the expert testified, rivals cannot succeed when introducing new products if their products are no better than those of incumbent market leaders. ${ }^{53}$ This testimony suggests that Microsoft would likely have anticipated maintaining a high market share if it and one or more of its operating system rivals introduced upgrades, even if the applications barrier to entry were reduced through antitrust enforcement.

Microsoft's expert also testified that entrants can win in software marketsoperating system markets included ${ }^{54}$ - by introducing new products that represent substantial improvements, ${ }^{55}$ and thereby displace current market leaders. ${ }^{56}$ If so, an operating system rival would be expected to take a great deal of

${ }^{51}$ This discussion presumes that when operating systems rivals foresaw the prospect that the applications barrier to entry would be reduced and their ability to compete with Windows increase, they would have an incentive to invest more in developing improvements to their own operating systems.

52 Microsoft's appropriability justification could also have been questioned on the ground that its payoff from innovation in operating systems (the market Microsoft was found to have monopolized), and thus its incentives to invest in operating system R\&D, would likely have remained high even if its exclusionary conduct is prohibited, because network effects and customer switching costs meant Microsoft would profit through increased sales of complementary software. See supra note 16 and accompanying text. In order to focus the present discussion on the analytical framework for evaluating the way Microsoft would respond to rival $R \& D$, this possibility is assumed away.

${ }^{53}$ See Schmalensee, supra note 5, If 37 ("Competitors cannot win by introducing a trivial advance over existing leaders" in the microcomputer software industry "because that would require asking consumers to scrap investments in their current software for minimal gain"); see also id. IT 33 (Consumers "stay with the current leader until a product comes along that is sufficiently superior to warrant abandoning their investments in the leader."). The testimony was couched in terms of software generally, but it is evident that it was intended to apply to operating systems software in particular.

${ }_{54}$ See id. II 37 ("Entry and success in computer operating systems appears harder than for most microcomputer software categories" but it is "eminently feasible.").

${ }_{55}$ See id. II 37 ("Firms try to win by 'leapfrogging' the existing leader with substantial improvements.").

${ }^{56}$ See id. TII $32-36$. 
business from Microsoft by introducing a next-generation operating system when Microsoft did not. ${ }^{57}$

These two factors-Microsoft's likely high market share if it and rivals both innovated, and Microsoft's likely anticipation of substantial customer loss if a rival upgraded when Microsoft did not-suggest that Microsoft would have benefited more by improving Windows if its rivals improved their own operating systems than if its rivals did nothing..$^{58}$ If so, Microsoft would have been expected to respond to increased $R \& D$ investment by rivals-or, based on the facts of the case, to have responded to the likelihood that Microsoft's operating system rivals would have taken advantage of an erosion of the applications barrier to entry to develop upgraded operating systemsby increasing its own R\&D effort. ${ }^{59}$ Such an inference about Microsoft's likely behavior would have called into question Microsoft's claim, based on the appropriability logic, that antitrust enforcement would have lessened its incentive to innovate.

\section{B. IBM (Plug Compatibility)}

The IBM plug compatibility cases, which will be treated as a single case, involved competition in computer peripherals. ${ }^{60}$ During the late $1960 \mathrm{~s}$ and

${ }^{57}$ This aspect of the expert's testimony was offered in support of the expert's claim, contested by the government and rejected by the courts, that entry was easy in operating systems notwithstanding the challenged practices. The implication highlighted here, about the likely success of a new operating system introduced by a rival and not matched by Microsoft in the event the applications barrier were reduced, would have been less controversial.

${ }^{58}$ The third factor identified in Part I, Microsoft's profits from the sale of complementary products, seems unlikely to have influenced that firm's response to rival R\&D in operating systems. To conclude otherwise, one would need to suppose that operating system improvements would substantially increase the sales of Microsoft's applications programs, such as its Office suite.

${ }^{59}$ Microsoft argued for a product market that included middleware (such as browser software and Java) along with operating systems, suggesting that it viewed the two products as substitutes. United States v. Microsoft Corp., 253 F.3d 34, 35 (D.C. Cir. 2001). For that reason, and given the steps Microsoft took to integrate its browser into Windows, Microsoft may have viewed improvements in browsers as innovation in operating systems. If so, the browser feature competition between Microsoft's Internet Explorer and the rival Firebox browser during the mid-2000s can be understood as consistent with the view that Microsoft would treat rival operating system R\&D as a strategic complement. See, e.g., Erik Larkin, Radically New IE 7 or Updated Mozilla Firefox 2-Which Browser Is Better?, PCWORLD (Oct. 24, 2006), www.pcworld.com/article/ 127309/article.html (describing browser feature competition).

${ }^{60}$ Transamerica Computer Co. v. IBM, 698 F.2d 1377, 1383-84 (9th Cir. 1983); Cal. Computer Prods., Inc. v. IBM, 613 F.2d 727, 744 (9th Cir. 1979); Telex Corp. v. IBM, 510 F.2d 894 (10th Cir. 1975). The government's long-running case against IBM, which the government dismissed in 1982, addressed, in part, similar allegations. FrankLIN M. FISHER, JOHN J. MCGowan \& Joen E. Greenwood, Folded, Spindled, and Multilated: Economic Analysis and U.S. v. IBM 12,13-14, 360-68 (1983) (After an initial verdict in favor of private plaintiffs (later reversed) in Telex, the government added similar allegations.); id. at 1, 368-69 (The government sought dismissal after concluding that the case was "without merit."). Assistant Attorney General William Baxter ended the government's case notwithstanding his expectation that the govern- 
early 1970s, IBM was the leading manufacturer of central processing units (CPUs) for general purpose computers, and likely accounted for the majority of shipments. ${ }^{61}$ In addition, IBM, along with multiple rivals, sold peripheral equipment (tapes, disks, printers, and terminals) that worked with IBM's computers. IBM may have had a monopoly share in markets for plug-compatible peripherals during the early 1970 s. $^{62}$

When IBM introduced a new generation computer system in the early 1970 s, it changed the way peripheral equipment was connected. Its new CPUs were incompatible with the peripherals that worked with its prior generation computers and compatible only with new peripheral products sold by IBM. Several rival manufacturers of plug-compatible peripherals challenged this conduct as monopolization. ${ }^{63}$ In resolving this aspect of the cases, the courts implicitly accepted an appropriability justification for some of IBM's conduct: they declined to condemn IBM's product design decisions found to enhance product quality or reduced manufacturing costs, ${ }^{64}$ in part to avoid chilling that firm's incentives to innovate. ${ }^{65}$

ment would prevail at trial and on appeal. John E. Lopatka, United States v. IBM: A Monument to Arrogance, 68 AntrTRust L.J. 145, 146 n.6 (2000).

${ }^{61}$ IBM's share of general purpose computers (the market in the cases most closely related to CPUs) was estimated at 57\% in one case. In re IBM Peripheral EDP Devices Antitrust Litig., 481 F. Supp. 965, 981-82 (N.D. Cal. 1979) (accepting a 57\% share for the 1969 through 1975 period), aff'd, Transamerica Computer Co., 698 F.2d at 1381, 1382. In another case, witnesses for plaintiff asserted that IBM's market share in general purpose computers was between $60 \%$ and $80 \%$ for unspecified years, likely the early 1970 s, although IBM questioned those figures. California Computer Products, 613 F.2d at 738-39. A third district court cited internal IBM documents as estimating that firm's share of CPUs at $64 \%$ in 1968 and cited the U.S. Bureau of the Census as estimating that in 1971 IBM accounted for $41 \%$ of the value of shipments of "Electronic Computers, Digital, General Purpose" (not the same as CPUs, but the closest analog in the census data referenced). Telex Corp. v. IBM, 367 F. Supp. 258, 285-86 (N.D. Okla. 1973), rev'd, 510 F.2d 894. The appellate panel reviewing that decision characterized the district court as estimating IBM's market share at $35 \%$, apparently referring to a revenue share figure the district court cited for electronic data processing as a whole rather than specifically for CPUs. Telex, 510 F.2d at 899 .

${ }^{62}$ Telex, 367 F. Supp. at 286-90 (citing testimony that in 1970 IBM had revenue shares of $90 \%, 68 \%, 99.6 \%$ and $92.3 \%$ in various peripheral products, and IBM documents indicating unit shares of $80 \%, 94 \%$, and $99 \%$ for certain peripheral products); IBM Peripheral EDP Devices, 481 F. Supp. at $986-87$ (average market share of $54 \%$ for one peripheral product and $77 \%$ for another between 1969 and 1975). See California Computer Products, 613 F.2d at 738 (Plaintiff offered evidence that IBM's markets share in peripherals fell from $79 \%$ to $68 \%$ from 1970 to 1972; IBM's evidence was that its share was less than $30 \%$.).

${ }^{63}$ Plaintiffs also unsuccessfully alleged that price cuts by IBM on peripherals amounted to predatory pricing. California Computer Products, 613 F.2d at 743; Telex, 510 F.2d at 926, 928; IBM Peripheral EDP Devices, 481 F. Supp. at 1002; ILC Peripherals Leasing Corp. v. IBM, 458 F. Supp. 423, 433-34 (N.D. Cal. 1978), aff'd, Memorex Corp. v. IBM, 636 F.2d 1188 (9th Cir. 1980).

${ }^{64}$ California Computer Products, 613 F.2d at 744; IBM Peripheral EDP Devices, 481 F. Supp. at $1002-03$.

${ }^{65}$ An appropriate legal standard for design conduct "must properly balance a concern for the preservation of desirable incentives with the need to prevent monopolization by technology." 
To illustrate how an appropriability defense could have been evaluated in this setting using the framework set forth in Part I, the discussion will focus on IBM's incentives to develop next-generation peripherals, the markets that were allegedly monopolized through exclusionary conduct. ${ }^{66}$ The discussion will further suppose that antitrust enforcement would increase R\&D investment by rival manufacturers of peripherals. If IBM would respond to greater innovative effort by its peripherals rivals by increasing its own innovative efforts, that response would tend to undermine an appropriability justification for IBM's exclusionary conduct.

IBM would likely respond this way if it would expect to benefit more by developing next generation peripherals if its rivals also introduced upgraded peripheral products than by upgrading if its rivals did not innovate. ${ }^{67}$ The framework set forth in Part I suggests that whether this condition holds would depend importantly on three factors: (1) IBM's expected market share if all firms introduced new products, (2) IBM's expected customer loss if only its rivals upgraded, and (3) the consequences of new peripherals for the demand for computer systems, an important complementary product also sold by IBM.

Based on the description of the industry in the court opinions, it is plausible that IBM would have anticipated maintaining a high market share in peripherals if, absent the challenged incompatibility, both it and rivals had introduced next-generation products. Factors like customer loyalty, brand reputation, and service would likely have protected IBM's share to a substantial extent, ${ }^{68}$ although the fact that IBM's share in current generation peripherals had been declining could suggest otherwise. ${ }^{69}$ Moreover, that share decline, in a market

IBM Peripheral EDP Devices, 481 F. Supp. at 1003 . "Truly new and innovative products are to be encouraged . . . "Id. Modern courts take a similar view:

As a general rule, courts are properly very skeptical about claims that competition has been harmed by a dominant firm's product design changes. In a competitive market, firms routinely innovate in the hope of appealing to consumers, sometimes in the process making their products incompatible with those of rivals; the imposition of liability when a monopolist does the same thing will inevitably deter a certain amount of innovation. . . . Judicial deference to product innovation, however, does not mean that a monopolist's product design decisions are per se lawful.

United States v. Microsoft Corp., 253 F.3d 34, 65 (D.C. Cir. 2001) (citation omitted).

${ }^{66}$ IBM could also have argued that relief that would limit its ability to profit in the sale of peripherals could chill its incentives to develop improved computer CPUs, a complementary product. Evaluating such a claim would require a separate analysis not undertaken here.

${ }^{67}$ Supra note 39 and accompanying text.

${ }^{68}$ IBM maintained a substantial market share in peripherals for years after rivals developed peripherals compatible with IBM's new generation computer.

${ }^{69}$ Telex Corp. v. IBM, 367 F. Supp. 258, 287, 290 (N.D. Okla. 1973), rev'd, 510 F.2d 894 (10th Cir. 1975); California Computer Products, 613 F.2d at 738. The parties disagreed over the speed and extent of the share decline. Id. If the pre-innovation share decline was substantial and rapid, it could have suggested instead that IBM would not have kept a high peripherals share in the event both it and its rivals introduced new products and that IBM would have regarded rival $R \& D$ as a strategic substitute, consistent with an appropriability defense. 
in which both IBM and rivals introduced new products, suggests that rivals would have taken substantial peripheral business away from IBM by upgrading peripherals if IBM did not also do so. ${ }^{70}$

Together these two factors suggest that IBM could have benefited substantially by upgrading peripherals in the event its rivals also did so. By innovating, IBM may have been able to avoid the costly outcome in which only its rivals introduced new products, and IBM could have earned substantial profits in the event both it and its rivals upgraded. The difference in profitability between those outcomes could well have exceeded the incremental gain to IBM from introducing new peripherals in the event it was the only firm to do so. If so, IBM would likely have responded to greater innovative effort by its peripherals rivals - as might have been the product of antitrust enforcement against IBM's conduct-by increasing its own innovative effort. Such a response would provide a basis for questioning an appropriability defense.

This tentative conclusion could be overturned by considering the consequences of the development of next generation peripherals for the sale of computer central processing units, a complementary product in which IBM likely had a high share. ${ }^{71}$ If new peripheral products would have led customers to buy new computers from IBM regardless of which firm sold the peripherals, ${ }^{72}$ and if computer sales were much more profitable to IBM than peripheral equipment sales, then IBM would have benefited from the introduction of new peripherals regardless of whether the new products came from IBM or its rivals. That could mean that the incremental benefit to IBM from innovating in peripherals would have been greater if rivals did not innovate than if they did, contrary to what was suggested by considering only the first two factors. Upgrading its peripherals when rivals did not do so would have boosted IBM's computer demand, while upgrading its peripherals when rivals introduced new products would not have added much to computer demand (which would already have gone up with the peripheral introductions of IBM's rivals).

${ }^{70}$ Some customers who would have preferred IBM's peripheral products if both IBM and its rivals offered same-generation products would likely have adopted rival products if the rivals introduced new products while IBM did not.

71 The discussion in this paragraph assumes that the dominant firm's sale of complements is not a market factor that ensures that the dominant firm will continue to profit greatly from R\&D investment even if it is prohibited from undertaking exclusionary conduct. Supra note 16 and accompanying text. If that assumption is incorrect, and the dominant firm's payoff to R\&D investment would remain high after antitrust enforcement because it would expect to profit in an increased sale of computer central processing units, the dominant firm would continue to have a strong incentive to invest in peripheral products $R \& D$ even if it did not regard rival $R \& D$ as a strategic complement, making it unnecessary to apply the analytical framework set forth in this article.

72 See Fisher ET AL., supra note 60, at 310 ("Success in systems placement depends on the attractiveness of peripherals."). 
IBM thus might have responded to antitrust enforcement by cutting back on its own effort, consistent with what an appropriability defense would maintain, if the profitability of complementary products was the dominant influence on IBM's response to rival innovative effort. ${ }^{73}$ But there is reason to question whether IBM's profits on CPUs were so much more profitable than its profits on peripheral sales as to be the primary consideration in undertaking peripheral $R \& D,{ }^{74}$ and thus to question whether the presence of complements would lead IBM to treat rival R\&D as a strategic substitute rather than a strategic complement.

\section{Xerox (Patent Portfolio)}

In 1975, the Federal Trade Commission and Xerox-then the dominant firm in plain paper copying-agreed to settle by consent an FTC case concerned largely with Xerox's accumulation of patents. ${ }^{75}$ The FTC's chief economist at the time later explained that the case centered on "the extension over time of [Xerox's] monopoly through patent accumulation." ${ }^{76}$ The FTC was concerned that that Xerox's extensive patent portfolio discouraged competi-

${ }^{73}$ Even if IBM would cut back on its own R\&D in peripheral products in response to greater innovative effort by its rivals-in which case the indirect effect on its incentives to invest in R\&D would work in the same direction as the direct effect-both effects could be small. That is, even after accounting for the loss of appropriability and IBM's response to greater rival R\&D, IBM's incentive to invest in new peripherals (as a way to boost the sale of central processing units) could remain high. If so, IBM's sale of complements would operate as a market factor ensuring that the dominant firm will continue to profit greatly from $R \& D$ investment even if it is prohibited from undertaking exclusionary conduct. Supra note 16 and accompanying text. This possibility, which was assumed away, would justify a rejection of IBM's hypothetical appropriability defense without a need to apply the analytical framework set forth in this article (and without regard to whether IBM treated rival R\&D as a strategic complement or strategic substitute). Infra text accompanying note 100 .

${ }^{74}$ Peripheral equipment was responsible for $50 \%$ to $70 \%$ of computer system prices. Telex, 367 F. Supp. at 277 . It would be possible for CPUs to account for the lion's share of IBM's profits if IBM earned narrow profit margins on peripheral equipment and large margins on CPUs. IBM's margins on peripherals were not small, however. IBMs margins on disk products were reportedly $47 \%$ to $58 \%$ before IBM cut prices in 1970 , in conjunction with its introduction of an upgraded CPU, and at least 20\% (and in one case 33\%) afterwards. California Computer Products, 613 F.2d at 740 n.19. IBM anticipated that a new memory unit would earn a margin of at least $20 \%$. Telex, $367 \mathrm{~F}$. Supp. at 306 . Given these estimates, it is unlikely that CPU margins could be high enough for IBM to care about peripheral innovation primarily as a means of stimulating CPU sales.

75 Xerox Corp., 86 F.T.C. 364 (1975) (Decision \& Order). See generally Willard K. Tom, The 1975 Xerox Consent Decree: Ancient Artifacts and Current Tensions, 68 Antitrust L.J. 967 (2000). The FTC's complaint also challenged marketing practices for products covered by the patents.

${ }^{76}$ Roundtable Discussion on Competition Policy, Intellectual Property and Innovation Markets, in Robert D. Anderson \& Nancy T. Gallini, Competition Policy and Intellectual Property Rights in the Knowledge-Based Economy 447, 449 (1998) (remarks of Professor F.M. Scherer). 
tion. ${ }^{77}$ Under the settlement, Xerox agreed to license its patents for a small royalty.

Although the FTC's legal theories would likely be thought of as adventurous today, ${ }^{78}$ the FTC's remedy "accomplished a world of good": $:{ }^{79}$ it appears

${ }^{77}$ Patent aggregation could inhibit price competition in product markets. It also could discour-
age innovation by a dominant firm's rivals, and thus potentially reduce innovation overall, for
multiple reasons. Cf. BRONWYN H. HALL, CHRISTIAN HELMERS, GEORG vON GRAEVENTIZ,
CHIARA RosAZZA-BoNDIBENE, A STUDY OF PATENT THICKETS (2013) (empirical study conclud-
ing that patent thickets in a technological area discouraged entry into that sector). First, patent
aggregation may discourage rivals from challenging weak patents by making it more difficult for
rivals to prove that a dominant firm's patents are invalid or narrow in scope. See United States v.
The Singer Mfg. Co., 374 U.S. 174 (1963) (Dominant firm's control of multiple patents in-
creased its likelihood of success in proving patent infringement by an importer with rapidly-
increasing U.S. sales.); id. at $177 \mathrm{n} .2,180,190$ (Dominant firm acquisition of control over multiple patents reduced the likelihood that those patents would have their claims narrowed or collectively be declared invalid.); $i d$. at 198-200 (White, J., concurring) (Patent cross-licenses and acquisitions lessened the likelihood that a potential rival or court would uncover information about the nature and scope of prior art.). Second, a dominant firm's patent aggregation may discourage rival innovative effort by making it more costly for a rival to review and analyze its likelihood of prevailing in infringement litigation brought by the patent portfolio owner. David L. Schwartz, On Mass Patent Aggregators, 114 Colum. L. Rev. Sidebar 51, 64-66 (2014) (discussing the "numerosity problem"). Aggregation raises rivals' costs because it requires rivals to analyze many patents in response to an infringement claim. Third, the aggregation of multiple weak patents may increase the likelihood that some patent in the collection would be found valid and broad in scope, thereby adding complexity and difficulty to licensing negotiations and increasing the likelihood that the portfolio owner would assert infringement. Cf. Bronwyn H. Hall, Christian Helmers \& Georg von Gravenitz, Technology Entry in the Presence of Patent Thickets 1 (Nat'1 Bureau of Econ. Research, Working Paper No. 21455, 2015) (When products draw on innovations protected by large numbers of patents with fuzzy boundaries, that can lead to "holdup of innovations, increases in the complexity of negotiations over licenses, increases in litigation" and "create incentives to add more and weaker patents to the patent system," thereby "increase[ing] transaction costs, reduc[ing] profits that derive from the commercialization of innovation, and ultimately reduc[ing] incentives to innovate."). Fourth, when a dominant firm acquires weak patents, those transactions may shift patent ownership to a firm more likely to enforce the patents against product market rivals, given the dominant firm's ability to profit through product sales as well as through royalties. Cf. Mark A. Lemley \& Carl Shapiro, Probabilistic Patents, J. ECON. PERSP., Spring 2005, at 75, 88-90 (2005) (small product market rivals may have suboptimal incentives to challenge patents asserted against them). The government has challenged acquisitions in part for this reason. See, e.g., Amgen Inc., FTC No. C-4056 (Sept. 6, 2002) (Decision \& Order), www.ftc.gov/enforcement/cases-proceedings/0210059/amgen-inc-immunex-corporation (preventing a combination of patent portfolios that threatened to allow the merged firm to block future product market sales of IL-1 inhibitors by the only other firm developing a competing pharmaceutical product); see Final Judgment, United States v. Borland Int'l, Inc., 1992 WL 101767 (N.D. Cal. Mar. 13, 1992) (preventing an acquisition of a dominant firm by its leading rival under circumstances in which the dominant firm did not enforce uncertain copyright rights against a third firm but the merged firm would likely have done so); see also Competitive Impact Statement, United States v. Borland Int'l, Inc., 56 Fed. Reg. 56,096, 56,100 (Oct. 31, 1991); Catherine Fazio \& Scott Stern, Innovation Incentives, Compatibility, and Expropriation as an Antitrust Remedy: The Legacy of the Borland/Ashton-Tate Consent Decree, 68 Antitrust L.J. 45 (2000).

${ }^{78}$ See Tom, supra note 75, at 967 (stating that "many of the practices alleged in the complaint or prohibited by the order seem innocuous to modern eyes").

${ }^{79} \mathrm{Id}$. at 989 . 
to have spurred $R \& D$ investment and entry by new rivals, ${ }^{80}$ and to have woken up a lethargic monopolist, which then invested more as well. ${ }^{81}$ Firm conduct after entry of the consent order thus suggests that Xerox responded to increased rival investment in new product development by increasing its own innovative effort, ${ }^{82}$ and that industry incentives to innovate increased overall. ${ }^{83}$ These industry outcomes offer an after-the-fact reason to question an appropriability justification for Xerox's accumulation of patents.

With the benefit of hindsight, the framework set forth in this article can be used to illustrate how an appropriability defense might have been evaluated as of the time of the settlement, had it been offered. Xerox may reasonably have anticipated that it would have kept a high market share if it and its rivals both introduced new products. Xerox likely had a strong brand reputation, an extensive sales and service network, and perhaps an installed base dominated by customers that had made investments in learning how to use its products, so it may have expected that any erosion in its market share would be slow. ${ }^{84}$ Such a prediction would have proven incorrect, as rivals successfully challenged Xerox's leading position during the years following the settlement. That outcome appears to have resulted mainly from the unanticipated entry of Japanese firms, rather than anticipated entry by IBM and Kodak. ${ }^{85}$ Thus, it could

${ }^{80}$ Cf. Michael E. Porter \& Yoko Ishikura, Canon Inc.: Worldwide Copier Strategy 12 (Harv. Bus. Sch. Case No. 9-384-151, 1988) (describing Canon's R\&D investment and patenting strategy during the late 1970s and early 1980s); id. at 14 (Canon's 1983 slogan proposed to "Catch Xerox through technological differentiation"); $i d$. at 15 (Exhibit 1) (listing 17 new plain paper copier models introduced by Canon in the United States between September 1972 and April 1983).

${ }^{81}$ Tom, supra note 75, at 978-79. Cf. Timothy F. Bresnahan, Post-Entry Competition in the Plain Paper Copier Market, 75 Am. ECON. Rev. (PAPERs \& Proc.) 15, 18 n.5 (1985) (deeming it hard to tell whether greater competition or new technological opportunities from the invention of microprocessors better explains the rapid increase in industry innovative activity); id. at 16-18 (After losing its monopoly, Xerox shifted from innovations in the copier to innovations in user interfaces, perhaps reflecting competitive pressure to develop improvements with more commercial interest than engineering interest.).

82 Xerox may have viewed its rivals' products (as distinct from rivals' investment in R\&D) as strategic substitutes, however. Bresnahan, supra note 81, at 17.

${ }^{83}$ To similar effect, the compulsory licensing of German chemicals patents to U.S. firms during World War I increased R\&D investment by both the German firms and their U.S. rivals after the war. See generally Joerg Baten, Nicola Bianchi \& Petra Moser, Does Compulsory Licensing Discourage Invention? Evidence from German Patents After WWI (Nat'l Bureau of Econ. Research, Working Paper No. 21442, 2015).

${ }^{84}$ Cf. Porter \& Ishikura, supra note 80, at 6 (indicating that in 1983, Canon had more than 600 U.S. dealers, for which it provided extensive financing and training in sales and service); $i d$. at 8-9 (describing Canon's brand advertising in the United States from 1978 to 1982).

${ }^{85}$ The FTC's chief economist at the time indicated that he expected IBM and Kodak to introduce copiers but did not anticipate the smaller and more reliable products introduced by Japanese firms. ANDERSON \& GALlINI, supra note 76, at 448 (remarks of Professor F.M. Scherer). By the early 1990s, Canon and Sharp both sold more copiers in the United States than Xerox, and Canon had a larger installed base. William R. Boulton, The Plain Paper Copier Industry 8 (1995), www.auburn.edu/ boultwr/copiers.pdf. 
have been sensible at the time for Xerox to forecast that it would keep a high market share. Xerox may also have anticipated that its advantages with customers would not have been sufficient to protect it from losing market share rapidly in the event rivals with strong reputations, such as IBM and Kodak, introduced next-generation products but it did not. ${ }^{86}$

If these suppositions about Xerox's view of the consequences of new product development are correct, then Xerox would have expected a substantial incremental benefit from upgrading its own copier products in the event rivals entered with new products. By developing a next-generation copier, Xerox would have expected to avoid substantial customer losses and preserve a high market share. Under such circumstances, the incremental benefit to Xerox of introducing a next-generation product would likely have been greater in the event rivals introduced new products than if rivals did not. ${ }^{87}$ Xerox, therefore, would have been expected to increase its innovative effort in response to a greater innovative effort by rivals. Such an anticipated response would have provided reason to question an appropriability justification for Xerox's patent accumulation.

\section{CONCLUSION}

This article has explained that a dominant firm's appropriability defense for exclusionary conduct should be questioned, and often rejected, if the firm would be expected to increase its own R\&D effort in response to increased R\&D by its rivals. This approach for evaluating an appropriability defense provides an additional argument beyond the main reasons offered in the economic literature: the empirical literature emphasizes the importance of competition relative to appropriability as a motive for innovation and raises the possibility that market factors would keep the dominant firm's payoff to innovation success high if its exclusionary conduct is prohibited.

A dominant firm's likely response to increased rival R\&D can be evaluated by analyzing its likely incremental gain from new product development if its rivals also introduce new products relative to its gain if its rivals do not upgrade their products. The analysis incorporates three potentially observable factors: the dominant firm's expected market share if it and its rivals introduce new products, its expected customer loss if only rivals do so, and the consequences of new product introduction for the dominant firm's profits from the

\footnotetext{
${ }^{86}$ Bresnahan, supra note 81 , at $16-17$ (entrants obtained a high share of new placements during the years in which Xerox did not compete with them on price.).

${ }^{87}$ Copier firms sold complementary products-mainly toner and paper-but most of their revenues came from copiers, and multiple firms produced complements. Thus, it is unlikely that the sale of complements influenced Xerox's strategic response to rival R\&D in copiers. See Porter \& Ishikura, supra note 80, at 5 (describing Canon's business in copier consumables and accessories as of 1983).
} 
sale of complementary products. Three examples from historical monopolization cases involving new product development illustrate the application of this analytical framework to evaluate appropriability defenses in individual cases.

The case studies apply the proposed analytical framework in an informal way, looking to three factors to determine whether the dominant firm would be expected to regard rival $R \& D$ as a strategic substitute or strategic complement. To assess the dominant firm's incentives quantitatively, as economists may seek to do in litigation, ${ }^{88}$ it would be necessary to estimate its incremental profit from innovation in the event its rivals innovate and compare that to its incremental profit in the event its rivals do not. ${ }^{89}$

The three case studies are intended to illustrate the analytical approach, not to establish definitively whether an appropriability defense should have been accepted in those cases. Still, as a group, they suggest that it would be neither unusual nor surprising for dominant firms to respond to new product development efforts of rivals with greater innovative effort of their own. That was a plausible interpretation of the facts in each case, and borne out in retrospect with respect to Xerox. This observation supports other reasons in the economic literature for skepticism about relying on an appropriability justification as a basis for framing antitrust rules or developing enforcement policy regarding dominant firms. ${ }^{90}$

\footnotetext{
88 See John Woodbury, Paper Trail: Working Papers and Recent Scholarship, AntrTRust SOURCE (Apr. 2015), www.americanbar.org/content/dam/aba/publishing/antitrust_source/apr15_ full_source.authcheckdam.pdf (reviewing the working paper predecessors to this article and the companion economic article) ("It would be helpful to design an 'appropriability arithmetic' that can place critical thresholds on the combination of these two factors [the dominant firm's share if it and its rivals innovate, and its share losses if rivals innovate but it does not] that would allow a more concrete prediction." Id. at 7.).

${ }^{89}$ Supra note 39 and accompanying text.

${ }^{90}$ The other reasons are described briefly supra at text accompanying notes $12-16$.
} 


\section{APPENDIX \\ ECONOMIC FACTORS INFLUENCING A \\ DOMINANT FIRM'S STRATEGIC RESPONSE TO RIVAL R\&D INVESTMENTS}

This appendix draws upon the results in the related economic theory article $^{91}$ to identify factors affecting whether a dominant firm would increase its $R \& D$ investment in new product development in response to greater R\&D investment by its rivals. The related article shows that the direction of the dominant firm's response depends on whether it gains more from innovation in the event other firms innovate too, relative to how much it would gain in the event that others do not innovate. ${ }^{92}$

That comparison depends upon the dominant firm's likely payoffs from innovation in four states of the world: $:{ }^{93}$ its payoff from developing a new or next-generation product in the event its rivals also do so $\left(\Pi^{\text {ss }}\right)$, its payoff from developing a new or next-generation product if it is the only firm to do so $\left(\Pi^{\mathrm{sf}}\right)$, its payoff in the event its rivals develop a new or next-generation product and it does not $\left(\Pi^{\mathrm{fs}}\right)$, and its payoff in the event no firm succeeds in developing new or next-generation products $\left(\Pi^{\mathrm{ff}}\right)$. The related article shows that the dominant firm has an incentive to increase its $R \& D$ investment in response to an increase in R\&D investment by its rival if the dominant firm's incremental gain from innovation success when its rivals also succeed $\left(\Pi^{\mathrm{ss}}-\Pi^{\mathrm{fs}}\right)$ exceeds the dominant firm's incremental gain from innovation success when its rivals do not innovate $\left(\Pi^{\mathrm{sf}}-\Pi^{\mathrm{ff}}\right)$, or when $\Delta=\left(\Pi^{\mathrm{ss}}-\Pi^{\mathrm{fs}}\right)-\left(\Pi^{\mathrm{sf}}-\Pi^{\mathrm{ff}}\right)>0$.

The expression $\Delta$ represents the incremental benefit of innovation success to the dominant firm conditional on rival success, net of the incremental benefit of innovation success conditional on rivals not innovating. The magnitude of the dominant firm's $R \& D$ response to rival $R \& D$ investment (the slope of its reaction function) is an increasing function of $\Delta .{ }^{94}$ The example in this

\footnotetext{
${ }^{91}$ Baker, Exclusionary Conduct, supra note 11.

${ }^{92}$ The sign of the slope of the dominant firm's reaction function determines the direction of indirect effect of dominant firm conduct excluding rivals from a product market on the dominant firm's incentives to invest in R\&D, discussed supra note 29 and accompanying text. The direct effect of the exclusionary conduct also depends on the magnitude of the reaction function's shift.

${ }^{93}$ In the notation, the first superscript indicates whether the dominant firm's innovative effort succeeds (s) or fails (f), and the second superscript indicates whether its rivals succeed or fail.

94 This relationship is implied by equation (3) in Baker, Exclusionary Conduct, supra note 11, at 7. (The dominant firm's best response function defined there, where it is denoted $R^{l}$, expresses rival $R \& D$ investment as a function of dominant firm investment. In this discussion, the reaction function has been inverted: the dominant firm's R\&D investment is expressed as a function of rival $R \& D$ investment. Hence equation (3) in that article implies that $d\left(R^{1}\right)^{-1} / d \wedge>0$.)
} 
appendix identifies economic factors that affect the size of these payoffs, and thus the relative magnitudes of the two incremental gains and the sign of $\Delta .{ }^{95}$

Suppose that two firms, a dominant firm and a rival, participate in a market. If neither firm innovates, both firms charge price $\mathbf{P}^{0}$, the industry collectively sells output $\mathrm{Q}^{0},{ }^{96}$ the dominant firm's pre-innovation market share is $\mathrm{S}^{0}$ (with $\left.0 \leq \mathrm{S}^{0} \leq 1\right)$, and the dominant firm's marginal cost is $\mathrm{C}$. Then, $\Pi^{\mathrm{ff}}=\left(\mathrm{P}^{0}-\right.$ C) $\mathrm{S}^{0} \mathrm{Q}^{0}$. If either firm succeeds in developing the new product, market demand shifts out, so industry output increases to $\mathrm{Q}^{1}$ (with $\mathrm{Q}^{1} \geq \mathrm{Q}^{0}$ ). Firms offering the new product sell it at price $\mathrm{P}^{1}$, which may exceed the price of previous generation products $\left(\mathrm{P}^{1} \geq \mathrm{P}^{0}\right)$. If the rival does not succeed, the dominant firm captures the entire market, so $\Pi^{\mathrm{sf}}=\left(\mathrm{P}^{1}-\mathrm{C}\right) \mathrm{Q}^{1}$. If the rival also succeeds, the dominant firm's anticipated post-innovation market share is $S^{1}$ (with $\left.0 \leq S^{1} \leq 1\right)$, so $\Pi^{\text {ss }}=\left(P^{1}-C\right) S^{1} Q^{1}$. Finally, if the rival succeeds but the dominant firm does not, the dominant firm cannot charge more than $\mathrm{P}^{0}$ and it loses $\mathrm{Q}^{\mathrm{d}}$ customers to its rival (with $\mathrm{Q}^{\mathrm{d}} \leq \mathrm{S}^{0} \mathrm{Q}^{0}$ ). ${ }^{97}$ The rival may not gain the entire market because the rival's new product may not be good enough to overcome customer switching costs or factors like brand loyalty that may protect the dominant firm's market share from complete erosion. Hence, $\Pi^{\mathrm{fs}}=\left(\mathrm{P}^{0}-\mathrm{C}\right)\left(\mathrm{S}^{0} \mathrm{Q}^{0}-\mathrm{Q}^{\mathrm{d}}\right)$. The four payoff terms are best viewed as present discounted values of a stream of future profits. ${ }^{98}$

In this example, $\Delta$ becomes

$$
\text { (1) } \begin{aligned}
\Delta & =\left(\Pi^{\mathrm{ss}}-\Pi^{\mathrm{fs}}\right)-\left(\Pi^{\mathrm{sf}}-\Pi^{\mathrm{ff}}\right) \\
& =\left[\left(\mathrm{P}^{1}-\mathrm{C}\right) \mathbf{S}^{1} \mathrm{Q}^{1}-\left(\mathrm{P}^{0}-\mathrm{C}\right)\left(\mathrm{S}^{0} \mathrm{Q}^{0}-\mathrm{Q}^{\mathrm{d}}\right)\right]-\left[\left(\mathrm{P}^{1}-\mathrm{C}\right) \mathrm{Q}^{1}-\left(\mathrm{P}^{0}-\mathrm{C}\right) \mathbf{S}^{0} \mathrm{Q}^{0}\right] \\
& =\left(\mathrm{P}^{0}-\mathrm{C}\right) \mathrm{Q}^{\mathrm{d}}-\left(1-\mathrm{S}^{1}\right)\left(\mathrm{P}^{1}-\mathrm{C}\right) \mathrm{Q}^{1} .
\end{aligned}
$$

Equation (1) is intended to provide intuition about the factors influencing $\Delta$; it is not a formula that would be calculated when evaluating the likely nature of dominant firm conduct in individual cases.

The dominant firm regards its rival's $R \& D$ investment as a strategic complement if $\Delta$ is positive $(\Delta>0)$, and as a strategic substitute if $\Delta$ is negative

\footnotetext{
${ }^{95}$ It is termed an example rather than a model because it does not indicate how prices, industry output, or market shares are determined. Moreover, in the states of the world in which the dominant firm successfully innovates, the part of the dominant firm's payoff that would come from profits on sales made before the new product is made available is ignored. Similarly, if the dominant firm does not innovate but its rival does, the dominant firm's profits arising from sales made before the rival makes its new product available are ignored.

${ }^{96}$ The quantity sold in this and other states of the world may be thought of as cumulative over the life of the product, with discounting ignored (or else with payoffs discounted under the assumption that prices increase over time at the dominant firm's discount rate).

${ }^{97}$ The difference between the rival's price and the dominant firm's price could be understood as reflecting the value of product improvements to the marginal buyer.

${ }_{98}$ This point may be important, for example, in evaluating forgone profit terms in industries in which rivals have been gaining share in the pre-innovation setting and may be expected to garner an increasing share over time in the event all firms innovate.
} 
$(\Delta<0)$. In equation (1), the sign is determined by the relative size of the two (positively-signed) terms in the final line: $\left(\mathrm{P}^{0}-\mathrm{C}\right) \mathrm{Q}^{\mathrm{d}}$ and $\left(1-\mathrm{S}^{1}\right)\left(\mathrm{P}^{1}-\mathrm{C}\right) \mathrm{Q}^{1}$. Those two terms represent profits captured from the dominant firm by its rivals in different states of the world. The expression $\left(\mathrm{P}^{0}-\mathrm{C}\right) \mathrm{Q}^{\mathrm{d}}$ accounts for the reduced contribution to dominant firm profits from sales lost to rivals in the event that rivals innovate and the dominant firm does not, relative to what the dominant firm would earn if neither it nor its rivals innovate. The second term, $\left(1-S^{1}\right)\left(P^{1}-C\right) Q^{1}$, reflects the lost contribution to dominant firm profits from sales lost to rivals in the event both it and its rivals innovate, relative to what the dominant firm would earn if only it innovates.

Equation (1) shows that $\Delta$ is an increasing function of both $\mathrm{S}^{1}$ and $\mathrm{Q}^{\mathrm{d}}$. A high anticipated market share for the dominant firm in the post-innovation product market in the event the dominant firm and its rival both introduce new products (a high $S^{1}$ ) raises $\Delta$ by increasing the dominant firm's incremental benefit of innovation success when its rival also succeeds (that is, by increasing $\Pi^{\mathrm{ss}}$ ). A substantial loss of customers from the dominant firm to its rival in the event that the rival develops a new or next-generation product while the dominant firm does not (a high $\mathrm{Q}^{\mathrm{d}}$ ) raises $\Delta$ by increasing the incremental payoff to the dominant firm from innovating when its rival succeeds (that is, by reducing $\Pi^{\mathrm{fs}}$ ), because it reduces the dominant firm's payoff when its rival succeeds and the dominant firm does not. Thus, increases in both $S^{1}$ and $Q^{d}$ raise the dominant firm's incremental gain from innovation success in the event its rivals also succeed $\left(\Pi^{\mathrm{ss}}-\Pi^{\mathrm{fs}}\right)$.

The extent to which the dominant firm's increased profits from the sale of complements matters for the sign of $\Delta$ depends on the nature and extent of competition in complementary products markets. At one extreme, if the dominant firm is the only seller of the complementary products, it may be reasonable to suppose that it will earn the same additional contribution to profit in complementary goods markets when a new product is introduced, regardless of whether it, its rival, or both successfully innovate. ${ }^{99}$ Adding this feature to the example lowers $\Delta$ relative to the expression set forth in equation (1). If $\Phi$ represents the total incremental profits available from the sale of complementary products resulting from the introduction of a new product, and the dominant firm expects to capture them regardless of which firm innovates, then

\footnotetext{
${ }^{99}$ But perhaps not. If rivals innovate but the dominant firm does not, and if most of the dominant firm's customers would switch to products sold by rivals, the strategic interaction between the two firms selling complementary products-one a sole seller (the dominant firm in the complementary product) and the other nearly so (the rival in the primary product) - would affect the margin the dominant firm receives on the complementary product. In particular, if the two firms treat their products as Cournot complements, the margin on the primary product could rise. Alternatively, and to similar effect, if primary market competition between the dominant firm and its rival remains important, the dominant firm could increase the margin on the complementary product in order to soften primary market rivalry.
} 
$\Delta^{*}=\left\{\left[\left(\Pi^{\mathrm{ss}}+\Phi\right)-\left(\Pi^{\mathrm{fs}}+\Phi\right)\right]-\left[\left(\Pi^{\mathrm{sf}}+\Phi\right)-\Pi^{\mathrm{ff}}\right]\right\}=\Delta-\Phi<\Delta$. For $\Phi$ sufficiently large, $\Delta^{*}<0$, implying that the dominant firm treats rival $R \& D$ as a strategic substitute regardless of the sign of $\Delta$. Intuitively, if the dominant firm's profits from the introduction of a next-generation primary product mainly derive from the profits it receives through increased sale of complements, then the dominant firm gains a great deal from introducing an upgraded primary product when its rival does not but gains little from developing its own new product when its rival has done so. Under such circumstances, the dominant firm would be expected to respond to a reduction in rival $R \& D$ by increasing its own $R \& D$ investments and respond to an increase in rival $R \& D$ by reducing its own investments.

The above analysis of the role of complementary goods in determining the sign of $\Delta$ depends critically on the assumptions that overall profits are dominated by profits in the sale of complementary products and that the dominant firm is the only seller of complementary products. If instead the dominant firm and its rival both sell complementary products, and the dominant firm earns additional profits from the sale of complementary products following the introduction of the new product only if it sells the new product, then $\Delta$ would still be lower than the expression set forth in equation (1)-but not by much if the dominant firm's anticipated market share is large. In particular, if the dominant firm's share of the incremental profits available from the sale of complementary products depends on its share of sales of new products, then $\Delta^{* *}=\left\{\left[\left(\Pi^{\mathrm{ss}}+\mathrm{S}^{\mathrm{I}} \Phi\right)-\Pi^{\mathrm{fs}}\right]-\left[\left(\Pi^{\mathrm{sf}}+\Phi\right)-\Pi^{\mathrm{ff}}\right]\right\}=\Delta-\Phi\left(1-\mathrm{S}^{\mathrm{l}}\right)$, which approaches $\Delta$ as $S^{1}$ approaches one. Moreover, and at the other extreme, if multiple firms sell the complementary product, and the dominant firm would not expect to make many incremental sales or would expect to earn only a small margin on any incremental sales it does make, then the sale of complements would make little difference to $\Delta$ and, in consequence, not affect the dominant firm's R\&D investment decisions.

Even if the dominant firm regards rival R\&D investment as a strategic substitute, the possibility that the dominant firm is also the dominant seller of highly profitable complementary products could operate to ensure that the dominant firm will continue to profit greatly from $R \& D$ investment if it is prohibited from undertaking exclusionary conduct. ${ }^{100}$ While the indirect effect on its incentives to invest in $R \& D$ would work in the same direction from the direct effect under such circumstances, both effects would be small. This possibility would justify a rejection of the dominant firm's appropriability defense without the need to apply the analytical framework set forth in this article.

\footnotetext{
${ }^{100}$ Supra note 16 and accompanying text.
} 
Two implications of equation (1) are not emphasized in the text. First, equation (1) indicates that the greater magnitude of the innovation - the more the new product expands the market (higher $\mathrm{Q}^{\mathrm{l}}$ ) and the greater the value the new product offers customers (and thus the higher the post-innovation markup $\left(P^{1}-C\right)$ ) - the less likely the dominant firm is to regard its rival's R\&D investment as a strategic complement. The more the new product represents a major improvement over existing-generation products, the more the incremental benefit of innovating in the event its rival also innovates will be dominated by the dominant firm's payoff when both succeed $\left(\Pi^{\mathrm{ss}}\right)$, and the more its incremental benefit in the event the rival does not innovate will be dominated by its payoff when only it succeeds $\left(\Pi^{\mathrm{sf}}\right)$. Of the two, the latter payoff is greater because the dominant firm captures the market when it is the only successful innovator, while it is limited to the fraction $S^{1}$ when both firms succeed. In the limit as the innovation grows drastic, therefore, $\Pi^{\mathrm{sf}}$ will control the sign of $\Delta$, which will be negative. As the innovation becomes drastic, however, that raises the possibility, outside the example, that the dominant firm would continue to have strong incentives to invest in R\&D even if exclusionary conduct is prohibited because of the magnitude of the possible payoff, notwithstanding its likely strategic response to greater rival R\&D. ${ }^{101}$ Accordingly, this implication of the example is not relied on in discussing the case examples.

Second, equation (1) also shows that a high dominant firm profit margin pre-innovation (a lower $\mathrm{C}$, holding $\mathrm{P}^{0}$ constant) tends to lead the dominant firm to see its rival's R\&D investment as a strategic complement if the dominant firm's anticipated market share is high. The main reason is that, in the example, a high pre-innovation margin tends to mean that post-innovation margins will be even higher, increasing the dominant firm's incremental benefits of innovation success when its rival also succeeds (by increasing $\Pi^{\mathrm{ss}}$ ). But a higher margin also affects the dominant firm's payoffs in the other three states of the world, generating incentives that go in the opposite direction. In the example, the latter incentives would dominate if the dominant firm's anticipated market share is sufficiently small. ${ }^{102}$ However, the above interpretation of the significance of a high pre-innovation profit margin turns on a special feature of the example: the assumption that when both firms participate in the market (both succeed or both fail), they charge an identical price. For this reason, and because of well-known difficulties of measuring marginal cost, the discussion in the text does not discuss the dominant firm's pre-innovation price-cost margin when analyzing the case examples.

\footnotetext{
${ }^{101}$ Id.

${ }^{102}$ That is, $d N / d C<0$ if and only if $\left(Q^{d} / Q^{1}\right)+S^{1}>1$, which is satisfied only if $S^{1}$ is sufficiently high.
} 